\title{
THE SMELL OF LAW DECISIONS: OLFACTION IN BRAZILIAN SUPERIOR JUSTICE COURT
}

\author{
O CHEIRO DAS DECISÕES JURÍDICAS: O OLFATO NO SUPERIOR TRIBUNAL DE \\ JUSTIÇA BRASILEIRO
}

\section{Mateus de Oliveira Fornasier}

Doutor em Direito pela Universidade do Vale do Rio dos Sinos (UNISINOS). Professor dos Programas de Pós Graduação Stricto Sensu (Mestrado) e de Graduação em Direito da Universidade Regional do Noroeste do Estado do Rio Grande do Sul (UNIJUI).

E-mail: mateus.fornasier@gmail.com

Recebido em: 23/04/2019

Aprovado em: 03/05/2019

\begin{abstract}
This paper aims to study the sense of smell and its importance to society, focusing on legal interpretations as a case to demonstrate the irritations between different social systems (science and law, mainly). Its general hypothesis is that some modern conceptions, even though dressed in all scientific and methodic appearance through centuries, are preconceptions biased by social interests; and these preconceptions based several paradigms of knowledge through times, being that Law reasoning in jurisprudence about smell has absorbed this socially constructed conceptions that are being denied by the most actual science. The research has used mainly three research methods: phenomenological-hermeneutical, historical-evolutive, and inductive; its approach is transdisciplinar, quantitative and qualitative. Its technique of research is bibliographical and documental.
\end{abstract}

Keywords: olfaction; jurisprudence; Superior Justice Court.

RESUMO: Este artigo objetiva estudar o sentido do olfato e sua importância para a sociedade, focando-se em interpretações jurídicas como o caso para demonstrar as irritações entre diferentes sistemas sociais (ciência e direito, principalmente). Sua hipótese geral é de que algumas concepções modernas, apesar de terem sido revestidas em aparências científicas e metódicas através de séculos, são preconceitos enviesadas por interesses sociais; e esses preconceitos embasaram diversos paradigmas do conhecimento através dos tempos, de modo que o Direito arrazoado na jurisprudência sobre o olfato absorveu essas concepções socialmente construídas, as quais estão sendo refutadas pela ciência mais atual. A pesquisa se valeu, principalmente, de três métodos de pesquisa: fenomenológico-hermenêutico, histórico-evolutivo e indutivo. Sua abordagem é transdisciplinar, quantitativa e qualitativa. Sua técnica de pesquisa é bibliográficodocumental.

Palavras-chave: olfato; jurisprudência; Superior Tribunal de Justiça. 
CONTENTS: Introduction; 1 Function of the smell to human body and brain - 2 From the importance to animalization: smell and its cultural meaning - 3 The smell of Brazilian law order in jurisprudence - Conclusion - References.

\section{INTRODUCTION}

The human being is a conjunction between biological and psychic systems, which communicates with the society through the interpenetration of language (LUHMANN, 1995, p. 272). This last one has been significantly addressed, in law social theory, concerning to written, oral and visual language. However, other important senses for communicating (and understanding) of the world by the human being - such as the touch, the taste and the smell - has not been addressed that much.

Despite the scarce works about the smell in law social theory (SYNNOTT, 1991, p. 438) - maybe because of the disqualification Western scholars have constructed of the smell as being as expression of the animality since the 18th century (CORBIN, 2008, p. 337-338) -, much has been done about the senses in Social and Human Sciences. David Howes (2014, p. 10-26) traced a very detailed evolutionary line of sensory studies in History and Anthropology, for example, since the decade of 1980 . And that is a proof that it may not only be possible to associate, in Law studies, the sense of smell and what is being juridically communicated about it, but also a very promising way of thinking the Law in the society: "law, through its conventional association with reason, has been seen as opposed to, or at least situated outside, the realm of senses - although very much involved in its regulation" (HOWES; CLASSEN, 2014, p. 93).

Studying the smell means to explore an extremely complex type of communication, doted of very differentiated nuances and pragmatic, semantic and syntactic attribution of senses. Olfactory sense starts with molecules with special attributes in the outside world, what make possible that these molecules interact with sensory receptors in the nose, sending specific nerve impulse-patterns to the brain - which compares the incoming signal with other signal-patterns memorized and, depending upon whether or not it can find a matching pattern, assigns a meaning to the signal and decides on the most appropriate response (WRIGHT, 1982).

Practically every productive human activity (crafting, industrial and agricultural producing, mining, trading, etc.) that minimally involves a chemical reaction or a little stronger physical phenomenon will cause some aroma. Moreover, several living species communicate their intentions and behaviors through smell - specifically, through exhalation of pheromones, chemical substances that flow in the air from one individual to other, in order to produce a certain hormonal or behavioral reaction (marking territory, informing that is disposable to coupling, etc.) (HALPERN; MARTINEZ-MARCOS, 2003, p. 245-318). When human behavior is analyzed, it is clear that human techniques explore the production of certain smells as a way to communicate something to others. The memory evoked by smell is much more linked to the emotions than to consciousness (although one thing does not excludes absolutely the other).

The main goal of this work is to study the sense of smell and its importance to society, focusing on legal interpretations as a case to demonstrate the irritations between different social systems. To achieve this goal, the article was divided into three sections. The first one has the specific goal of showing what is the olfaction in human brain and psyche, according to the most current scientific discoveries. The second one, by its turn, shows that olfaction not only has a historical and cultural meaning, but also, that Modernity distorted its meaning in a non scientific way. And finally, after discussing on an autopoietical theory of Law decisions, the third one studies the jurisprudence of a specific important Court (Brazilian Superior Justice Court, or Superior Tribunal de Justiça, STJ, originally), in order to demonstrate that this modern preconceptions still take part on the decisional process nowadays. 
The research question that provoked initially this work can be described in this sense: in what way(s) conceptions formulated during the advent of Modernity about the sense of smell (or olfaction) can be observed in the jurisprudence of a Court? The general hypothesis for that question is that some modern conceptions, even though dressed in all scientific and methodic appearance through centuries, are preconceptions biased by social interests; and these preconceptions based several paradigms of knowledge through times, being that Law reasoning in jurisprudence about smell has absorbed this socially constructed conceptions that are being denied by the most actual science.

This research has used mainly three research methods: for the first item, a phenomenological-hermeneutical research was conducted, focused on the medical and psychological function of the smell; in relation to the second item, a historical-evolutive and anthropological research was conducted in order to understand the importance of the smell in the society; and in its third item, the research has used an inductive method, as all the possibilities of usage of "smell" and synonyms by the Brazilian Superior Court were studied and interpreted with all the theoretical framework built in the two precedent points.

Its approach is transdisciplinar, as sources from many sciences and fields of research (Neuroscience, Psychology, Social Sciences and Law, mainly) were studied in order to understand how the olfaction functions in the human being. But it is also quantitative (as a significant number of decisions on the matter is studied) and qualitative (because of the importance of the interpretations given to collected data).

Its technique of research is bibliographical and documental. Focusing on the jurisprudence research, an online survey at Brazilian Superior Court of Justice (Superior Tribunal de Justiça in Portuguese) website was done, being used the terms cheiro ("scent", in English), odor (a synonym to "scent" in Portuguese), olfato e faro (words in Portuguese that designates "olfaction", "the sense of smell", being the last one used more when related to a dog's sense of smell, for example). ${ }^{1}$ No initial and final chronological terms were imposed, but only the type of decision called acórdão (a judgement made by a collegiate organ of the Court, which represent the final decision on an appeal made to that court, and which is the last important decision made by STJ, on matters that do not verse about Brazilian Constitution directly).

These methodological choices can be easily justified here. In first place, a research with a good degree of abstraction and profoundness on smell in jurisprudence has to start with the understanding of a sense for human being. Secondly, it has to show cultural and social contextualization of this sense (as it is not only a subjective experience). And in third place, a good historical and geographical delimitation has to be done with the case to be studied, giving the research precision, contextualization and possibilities of future comparisons with other contexts.

\section{FUNCTION OF THE SMELL TO HUMAN BODY AND BRAIN}

The olfactory bulb is closer to brain structures responsible for emotions and long-term memory - what means that olfactory sense provokes emotions and older memories faster than other senses, which has to pass through the thalamus before; and the olfactory bulb is also part of

\footnotetext{
${ }^{1}$ Seven decisions of Brazilian Superior Court (Superior Tribunal de Justiça) were found that the word "smell", although it appears in the text of the decision, is not fundamental to the question. These were the described decisions: Recurso Especial 693.172/MG, Rel. Min. LUIZ FUX; Recurso Especial 840.011/PR, Rel. Min. LUIZ FUX; Agravo Interno no Agravo em Recurso Especial 389.062/DF, Rel. Min. HERMAN BENJAMIN; Agravo Regimental no Agravo em Recurso Especial 622.639/SP, Rel. Min. HERMAN BENJAMIN; Habeas Corpus 379.479/SP, Rel. Min. REYNALDO SOARES DA FONSECA; Agravo Interno no Agravo em Recurso Especial 992.525/SP, Rel. Min. PAULO DE TARSO SANSEVERINO; eHabeas Corpus 442.556/RJ, Rel. Min. REYNALDO SOARES DA FONSECA. All the references concerning to those decisions are in the end of this article.
}

Revista de Direito Brasileira | Florianópolis, SC | v. 23 | n. 9 | p 364-388 | Mai./Ago. 2019 
the so-called limbic system, a group of structures which support the brain work in areas such as emotions, behavior, motivation and long-term memory (SHAW, 2017, p. 58-59). Maybe this is why smells have unusual evocative characters, as well as the immediate attraction or repulsion to them.

Crying babies who were separated from their mothers stopped crying if someone could expose them to clothes recently used by their genitor (SULLIVAN; TOUBAS, 1998, p. 402-408). That could mean that not only biologically a smell can have functions, but also, that the first important social interaction between mother and son has a bond that passes fundamentally by the meaning of safeness that smell can have to babies. Moreover, since 1983 at least it has been shown that mothers who had only a brief contact with their newborns after a cesarean surgery were able to recognize their smells through only one t-shirt used by the baby, for example (PORTER; CERNOCH; MACLAUGHLIN, 1983, p. 151-154).

But not only for connections between people in order to give a recognition communication that links people since the early life the smell works: it also functions to give cultural parameters for rejecting the other. Smells that denote membership of an individual in a group promote cohesion of the collectivity, but also can alienate the different ones: that is why odors become an instrument and a justification, many times, for social, racial and moral rejection (LE GUÉRER, 1993, p. 27-30).

Attributing a meaning to smell involves, therefore, language - and language is doubly contingent: even when the emitter does not intend to produce an olfactive meaning with his/her emission, he/she can probably doing it - and this outcome will depend on both the recipient's perception and his/her (often affective) memory. Language

[...] functions in psychic systems without communication. Its true function lies in generalizing meaning with the help of symbols that - rather than designate something else - are themselves what they perform. Only in its function as a means of communication - which, from the viewpoint of evolution, seems to have been its original function - is language bound to coding, and thus to acoustic or optical signs for meaning (LUHMANN, 1995, p. 94).

Although it becomes clear by the reading of the previous excerpt, social systems theory has focused itself in the relationship between language and oral/written symbols; but it is also clear that: i) it was not excluded the possibility of generalizing meanings according to other subtracts of language, such as chemical or physical means: sound is a physical mechanical wave and writing depends also on chemical phenomena; ii) every symbolic generalization has meanings not only in communicative systems, but also in psychical ones - as it happens also to the attribution of meaning to chemical signs on the environment.

Communicating the availability to reproduction in several species, for example, is a very important function of smell. Pheromones are well-known substances used to this purpose. In this sense, Burton (1976, p. 111-112) also said that women are sensitive to substances that have musky odor - which, by their turn, are used as pheromones by male mammals of various species, and related to the male hormone, testosterone; moreover, that sensitiveness seems to increase during the period of ovulation in women. In addition, it was reported that the highest oestradiol and the lower progesterone levels were measured, the more attractive women's bodies were rated in research (LOBMAIER et al., 2018).

In this sense, producing a smell does not depends only on the intention of the one who does it - and several times, even when he/she intended to outcome with a specific meaning, the receiver maybe receives it in a totally diverse way. Back to the exemple of preparing food, the greatest chef of the world could cook the best beef, with the best receipt; but if a vegetarian feel 
the complex smell of the dish, he/she can not only find it repulsive, but it can also remember him/her of the conceptions and traumas that made him/her choose this kind of diet.

Engen (1989, p. 85) has studied for several years the relations between odor and cognitive memory, and posed that coming as odor is something very problematic, because there is no "universal" connection between a smell and a name (as it happens to colors, for example) proving that naming smells involves different semantic system. In his studies, it was found that while sight and other senses starts as functional ones, but turn into category differentiated with the age, smelling continues with its functional nomination. A good example of this is given by the author:

[...] Children define an orange as something to eat. It is not until they are about seven or eight years old that more abstract ways of describing category membership, such as "an orange is a fruit", become evident in their language. But we continue to name odors according to their functions as adults, when our descriptions of sights and sounds have changed (ENGEN, 1989, p. 85).

This was complemented by Degel (2000, p. 23), who analyzed the relationships between odor and implicit memory. In this sense, differently to what occurs to other senses like audition and vision, olfaction is a purely "nominative" one. But this is not exactly something that would pose olfactory perception as something poorer: recognizing the familiarity in a more immediate way seems to indicate that one of the main functions of the sense of smell is to perform as a warning system against dangerous factors in the surrounding air or in edible food.

However, this nominative character of smell has been proven as being a factor relative to the language that is spoken: English native speakers, for example, struggle when describing abstractly a smell (having to refer to the source of the smell almost uniquely), but there are some people from Thailand and Malay (Jahai and Aslian, respectively) who have a vast lexicon of abstract terms to abstractly describe smell (MAJID; BURENHULT, 2014, p. 266-270). By the way, this characteristic of having a vaster vocabulary to define smell abstractly has been more related to hunter-gatherers, when compared to agricultural and industrial peoples (MAJID; KRUSPE, 2018, p. 409-413).

Besides this consideration of a purely nominative character of smell sense, there are some other important considerations about smelling and memory. For example, it has been proved that, contrary to what happens to other senses (such as sight and hearing), smelling does not cue false memories, but only veridical ones (TAMMINES; MEBUDE, 2018). It would be possible that odor cue only to veridical memory is that, when compared to other sensory modalities, the olfactory input has a direct access to the hippocampus (which is a key to representation of veridical memories) SAIVE; ROYET; PLAILLY, 2014, p. 240); false memories, by their turn, arise in the temporal pole, where it is believed that abstract semantic knowledge are stores (CHADWICK, 2016, p. 10180-10185). Moreover, it has been also proven by science that olfactory cues are better than visual ones for triggering autobiographical memories (DE BRUIJN; BENDER, 2018, p. 547-558).

"The more familiar a person think an odor is, the more likable it is judged" (MARTIN, 2013, p. 38). And this is reinforced by the argument presented by Vroon et al. (1994, p. 86-87), who wrote that it is obvious the appreciation of smell: it is used to prefer certain kinds of certain plants or foods and to dislike the rotten or smelling like feces (which could infect someone through contact), and to make it easier for men to recognize familiar smells in the environment (what can help structuring the surroundings). 


\section{FROM THE IMPORTANCE TO ANIMALIZATION: SMELL AND ITS CULTURAL MEANING}

The importance of the sense of smell, as well as of the odors, has changed over time. Classen, Howes and Synnott (1994, p. 31) describe the importance of smell during life and after life to ancient Egyptians; the pleasure ancient Greeks and Romans had from intense sweet smells that no modern man could bear nowadays; the initial repulse that the first fathers of Christian Church had in relation to incense burning because of its association to pagan rituals (substituted posteriorly with the belief that there would be aromas associated to sanctity); the relationship between the withdrawal of miasmas of plagues and good scents in Middle Ages; and the revolution on sanitation and smell that walked besides Industrial and Urban Revolutions in the concerns for human and industrial waste that could cause diseases in cities (CLASSEN; HOWES; SYNNOTT, 1994, p. 13-92). Finally, the moral that science of sanitization imposed by the 19th century made sight overcome smell (CLASSEN; HOWES; SYNNOTT, 1994, p. 84): there was a significantly scientific preference for visual elements and tools, such as maps, microscopes and money, to the detriment of fragrant ones during those days - as well as the identification of smell as the sense of savages and animals (which are deprecated and exploited by western culture).

But it is also interesting to analyze what Social and Human sciences have researched on non-Western cultures and the meaning of smell. Time, space and people are measured, perceived and classified by a complex relationship between the senses in other cultures, having the smell an importance that decayed in the West since the 1800s.

The Andaman Islanders (Burma) built their calendar on the basis of a cycle of plant flowering scents, and they also differentiate the space where fragrant flowers grows (inlands) from those where the smell is salty (the shorelines) - and this perception is not a static one as it occurs in Western perception of space, as the smell of flowering depends on varying growth; the Dassanetch (Ethiopia) also have a calendar based on the cycle of scents - but, in their case, it is not the smell of flowers, but of fields burning (dry season) plants blooming (wet season). The Umeda (New Guinea), by their turn, calculate the distance not by the sight, but by the distance of a smell (as their culture make their olfactive sense extremely accurate). The Desana (Colombian Amazon) identify the territory occupied by a tribe through words that mean something like a place that has the tribe odor - as tribes are characterized by them according to the food they eat (and each kind of food exhales a typical scent); they also have moral, botanical and zoological systems based on smells. The Suya and the Bororo (both from Brazil) and the Serer Ndut (Senegal) built their systems of classes (of men, plants and animals) based on different types of smell (CLASSEN, 1993, p. 95-105).

The language of the Maniq, a nomadic hunter-gatherers people living in southern Thailand, is strongly based on smell, having it as an important reference point in a number of areas of life, such as medicinal practices and rituals, hunting, avoiding risks, etc. with a very abstract lexicon (or else, they do not express a smell simply referring to its source, as it happens in English language, for example) (WNUK; MAJID, 2014, p. 134). This capability of abstraction of smell language also happens to the Jahai people, hunter-gatherers from the Malay Peninsula (MAJID et al., 2018, p. 1-8).

Many cultures use odors as symbolically marks for classifying beings. The attractiveness/repulsiveness in olfactory experience turns scent into a very useful symbolic vehicle for categorizing according to cultural values, as well as investing classificatory systems with emotive power. The repugnancy of a kind of odor, for example, can reproduce the immediate physical repealing a society demands for a specific class or group of people. In this sense, characterizing a group as bad smelling is to make it repulsive or fragrant is to classify it at a very basic physical and emotional level (CLASSEN, 1993, p. 101). And these culturally 
constructed parameters for inclusion or exclusion serve as a basis not only for politically creating norms, but also, for jurisdiction about them.

Jurisdictions of smell can be exercised through legal and cultural frameworks of regulatory knowledge that are tempered according to normative notions of reasonableness. In this way, the normativity of reasonableness reflects cultural expectations that may be communicated through law. Law may regulate, control, and govern, but also constitutively reflect the culture of smell in which certain smellers are more powerful than others. Additionally, certain smells are less acceptable than other smells when present in public spaces. In public settings, smell marginalizes through associations with lack of personal hygiene, disregard for community standards, or simply not belonging. In these spaces, smell, or better yet, the right not to smell, is the extension of personal space to which rights frameworks are attached. In this way, the somatic notion of right extends beyond the body to that which the body can smell and receive those smells that bodies emit. We don't experience smell equally, and through smell, neither do we experience law or inclusion in community equally as well (MARUSEK, 2015, p. 36).

Hierarchies between people (physical, moral, economic, etc.), as well as measurement of time and space are important basis for legal cultures - and Western cultures, although may have formulated moral judgements and prejudices between classes related to smell (the smell of the working classes; the smell of poor; the smell of people of other places and races - or as it was put by George Orwell, "four frightful words... The lower classes smell") (1937, p. 159), may seem to follow an absence of smell in legal cultures. But prejudices associated with the cosmetically practices, food and professional activities were, in the dusk of Modernity, used as factor to attribute a certain rank (low or high, according to the context), to cultures and races who smelled in a certain way - this is shown about Native American, African, Chinese and, mainly, Jewish in texts written by British people 18th and 19th century (TULLETT, 2016, p. 318). "[...] There was a shift in the way that smell, beginning in the late nineteenth century, [that] was used to not simply demarcate groups but, in addition, to supposedly detect 'race' and ethnicity" (SMITH, 2012, p. 381).

Sovereignty is based on territory, which is put on maps based on (visual) meters, as well as estate property. Life expectancy is measured in countable years, months, hours, seconds which can be seen clockwise - as it occurs with the payment for labor: by time or by (countable) pieces. "Formerly power was personal, and therefore imbued with the smell of those who wielded it; now it has become impersonal and abstract, and therefore odorless" (CLASSEN; HELD; SYNNOTT, 1994, p. 161).

A decline of the sense of smell (and of all the non-visual senses) in modern Western culture may reveal not only a change in senses preferences, but mainly a shift in cultural and conceptual paradigms - and this was due the principal influence of the Enlightenment, which started influencing that paradigm by the second half of the eighteenth century (CLASSEN, 1993, p. 27): John Locke's Essay on Human Understanding emphasizes on the visual basis of mental activity (ONG, 1967, p. 66-68); René Descartes works also endorsed sight as the most important sense for technology and science (SYNNOTT, 1991, p. 70). Condillac (1930, p. xxxi) pointed out that "of all the senses it is the one which appears to contribute least to the cognitions of the human mind". Darwin (1874, p. 17) considered it it to be 'of extremely slight service", and for Kant (2006, p. 50) it was 'the most dispensable" of the senses.

Moreover, even the scientific understanding that poses human olfaction as being poorer than in other mammal species, for example, is a myth. It derives from a non-empirical hypothesis 
formulated by French anatomist and anthropologist Paul Broca, whose work had a lot of influence during 19th century (MACGANN, 2017). A chain of misunderstandings and exaggerations about the size of human olfactory bulb, such as its position in the brain and its size when comparing to other mammals, made the physician conclude that these facts would make olfaction an opposite of free will in human beings. Those mistakes were reproduced as true facts by Sigmund Freud during the following decades, basing lots of his work about human olfaction and psychoanalysis.

But lately science has shown that the human capability about olfaction must be evaluated not only in relation to other mammals capabilities, but according to other parameters. In other words, the primate olfactory system is highly sensitiveto many odors and can be strongly influential on emotions, physiology and behavior when properly tested(SCHAAL; PORTER, 1991, p 135-199; LASKA; SEIBT; WEBER, 2000, p. 47-53; LASKA et al., 2005, p. 302-311; SHEPHERD, 2004, p. 572-575). Different species have different sensitivities to different odorants, and when it concerns to human primates, our behavior is strongly influenced by olfaction - being that environmental can access specific memories and emotions, influence autonomic nervous system activation, shape perceptions of stress, prompt approach and avoidance (MACGANN, 2017, p. 4).

It is undeniable the influence of the Enlightenment theorization to legal culture in Western countries: constitutionalism, fundamental rights, tripartition of power, security and safeness, as well as the main importance of rationality are only some basilar examples one could quote. And this shift from synthesis to analysis that is represented by the shift from the importance of smell to sight (ONG, 1967, p. 74) may be verified: the importance of written (and pressed) text to Law, as well as the authority shift - from the person to the text - also reveal that.

Also in architecture it is seen, nowadays, that the aromatic dimension of built structures has been neglected in architectural theory - even thought "the effects created by odoriferous materials, ventilated scents and other wafting perceptions can significantly influence one's experience of a structure" (DROBNICK, 2005, p. 265). Of course, the structure described there is about an artificial building: Law is an artificial structure too, but it is immaterial, untouchable (yet a Law decision will cause lots of touches, scents, or privations of them). So what is the smell of the Law system? It could be said that Law, of course, has no physical smell, but there are communications Law makes of the physical sense of smell, providing a sense that is expressed in its propositions and decisions.

\section{THE SMELL OF BRAZILIAN LAW ORDER IN JURISPRUDENCE}

Social systems such as Politics, Religion, Economy, Science, Law, etc., are autopoietic they produce and reproduce their own elements by the interaction of its elements (TEUBNER, 1987, p. 3). Theories of autopoiesis are inspired in new discoveries in general systems theory in Biology, which poses that biological systems "[...] are characterized by a circular, recursive, selfreferential mode of operation", and this has dethroned the subject in its claim to be the unique referentiality (LUHMANN, 1988-1989, p. 137). In this sense, an autopoietic system's performance is based only in its own predecessor operations.

They are also functional systems - each social system constitutes itself in view of its own function. "The function is a problem that has to be solved at the level of the societal system [...]. Hence, autonomy is not a desired goal but a fateful necessity" (LUHMANN, 1990, p. 228). In this sense, legal norms "are a structure of symbolically generalized expectations" (LUHMANN, 2004, p. 146), being that Law uses counterfactually stabilized expectations (LUHMANN, 2004, p. 147); hence, the function of Law is stabilizing counterfactual expectations in society. 
Law cannot guarantee, of course, that these expectations will not be disappointed. But it can guarantee that they can be maintained, as expectations, even in case of disappointment, and that one can know this and communicate in advance. From the sociological point of view, then, normatively is nothing but counterfactual stability. To formulate this differently: in that it protects expectations, the law frees us from the demand that we learn from disappointments and adjust to them. It thereby holds out the prospect of resolving conflicts [...], for it contains a preliminary decision (however unclear it may be in the individual case) about who has to learn from disappointment and who does not (LUHMANN, 1988-1989, p. 140).

In this sense, Law not only imposes a social order; it not only organizes the violence of the State face to the society. These are all expressions of a "should be" based on what is communicated by a certain system used by professionals in solving conflicts based on what is expected of behaviors, even if the social experience shows that these norms are not being respected. Sociologically, Law would be like a social memory of what should and what should not be in social relations, even when socially the facts disappoint this "should" formula.

This is because there is a paradox of self-reference of Law in the most profound logic of the system, as it bases its present decision on its own past operations of selection. The system, in this sense, builds itself during each operation based on its own past operations (its program), formed by the application of a logical code (legal/illegal, when we analyze Law's code) posed by itself. Thus, everything that is not the system is its environment, and the system is closed in its operational logic, but highly dependent on its environment cognitivelly. Hence, Law system has a function, which is reflected in its structures (norms) - and its acts reflect the operations of the system. But the Law can also accept irritations of its environment, changing its norms - but it must be emphasized here that Law only changes when it is meaningful to Law, as only the system can (re)produce itself (LUHMANN, 1988-1989, p. 139).

There are juridical decisions which simply reproduce predecessor operations of the system, with no innovations (but only redundancy, confirmation of decisions from the past) (LUHMANN, 2005). But there are systemic decisions that innovate past operations, producing variation, introducing a difference into the system - being also argumentatively justified from past decisions (as it must be tolerated inside the system), but created primarily (PEREIRA; SIMIONI, 2009, p. 6506).

The positiveness of Law makes it an operatively closed system, but it is cognitively open because its decisions are directed to problems of the entire society (the environment of the system), which is translated to systemic elements (norms, acts, precedents, doctrine, etc.) (PEREIRA; SIMIONI, 2009, p. 6507). Then, Law needs an external reference to complete the lack of possibility of decision - a logical value that comes from the environment to complete the juridical argumentation (LUHMANN, 2004).

Besides all that decline of importance of smell in Western culture (also regarding Western Law), it does not mean Law cannot give a meaning to smell in its operations: it can be the external reference introduce in the system during the decision in order to make a judicial decision possible (even when it needs to be created). An analysis of what can be signified by a law order may clarify - and even help criticizing - what a specific sense means in practical decisions of a social system.

[...] The nose is used to distinguish legality from illegality, reasonableness from nuisance, and norm from deviance. In this way, the nose works to embody and instill a social and cultural response to normativity within a positivist framework of smell and polity. The smells of legality and illegality (such as those relating to alcohol, drunkenness, and marijuana smoke) heighten the sensory management of public space (through breathing, 
bodies, and odor) as legal methods through which social governance and cultural normativity relate to local ordinances and other forms of olfactorybased regulations (MARUSEK, 2015, p. 33-34).

Analyzing the jurisprudence of Brazilian Superior Court (STJ), it has to be pointed that bad smell, among other unhealthy factors, due to overcrowding of prison, is considered a factor of offense to the dignity of the human person (BRASIL, 2016c). ${ }^{2}$ However, expert proof is demanded in Brazilian decisions in order to confirm bad smell decurrent from malpractices in institutions, be them destined to attend incarcerated adults, be them designed to attend children and adolescents - and the State may be considered liable for indemnify these torts, as in Brazil, for the welfare of these subjects is their responsibility of the State (BRASIL, 2017i). ${ }^{3}$

Moreover, expert evidence is the basis not only for defining the area affected by bad smell caused by sewage, but also for indicating who is legitimated to sue for material and moral torts in that situation (BRASIL, 2017k). ${ }^{4}$ By the way, the State is also civilly liable for damage to individual homogeneous interest arising from poor provision of public sewage treatment service, where bad smell and other unhealthy conditions will affect the well-being of the perpetrator - and expert evidence is fundamental to the definition of such unsanitary conditions (BRASIL, 2018a, 2013a, 2014b, 2014c). ${ }^{5}$ It is interesting to notice, in addition, that the same court does not consider as being a hypothesis of civil liability the founding of a human corpse in a public water reservoir when the specialist evidencing does not encounter alterations in odor, color or microbiological presence in that place (BRASIL, 2015b). ${ }^{6}$

Furthermore, it has also been decided that when the expert evidence points that bad smell provoked by the installation of sewage plant does not depreciate a property (or does not cause any other inconvenience), there is no tort (BRASIL, 2012a). ${ }^{7}$ And also, this liability is considered as a non-contractual one, being given that to the value of the indemnification of these torts must be added interest rates counted since the beginning of the tort (or else, the date when the odoriferous inconvenience started) (BRASIL, 2018j). ${ }^{8}$ Specialist evidence is also fundamental when judging companies for crimes and civil liability related to air pollution when bad odors are emitted by factories (BRASIL, 1994, 20171, 2018d). ${ }^{9}$

Concerning to drug traffic evidencing in Brazil, it has been decided that a strong smell of narcotic substances (found as such in expert evidence and/or police testimony) encountered among the belongings of a suspect, justify his/her provisional prison (BRASIL, 2017h) ${ }^{10}$ or criminal prosecution (BRASIL, 2013b, 2015c, 2015d, 2016b, 2017f, 2017n, 2018c, 2018e, 2018h, 2018g, 2018i). ${ }^{11}$ Sniffer dogs' olfaction is also accepted as means of proof for the

\footnotetext{
${ }^{2}$ Recurso em Mandado de Segurança 46.701/MG.

${ }^{3}$ Recurso Especial 1653359/MG.

${ }^{4}$ Recurso Especial 1693951/RS

${ }^{5}$ Agravo Interno no Agravo em Recurso Especial 1207215/PR, Agravo Regimental no Agravo em Recurso Especial 401.510/RJ, Agravo Regimental no Agravo em Recurso Especial 462.242/RJ and Agravo Regimental no Recurso Especial 1346198/RJ.

${ }^{6}$ Agravo Regimental no Recurso Especial 1560641/MG.

${ }^{7}$ Agravo Regimental no Agravo em Recurso Especial 113.877/MS.

${ }^{8}$ Recurso Especial 1718176/RS.

${ }^{9}$ Recurso Especial 32.103/SP, Recurso Ordinário em Habeas Corpus 63.357/PA, Habeas Corpus 409.361/AM.

${ }^{10}$ Habeas Corpus 415.574/MG.

${ }^{11}$ Recurso Ordinário em Habeas Corpus 34.981/PR, Habeas Corpus 305.308/SP, Habeas Corpus 337.247/SP, Habeas Corpus 364.024/SC, Habeas Corpus 378.323/SC, Recurso Ordinário em Habeas Corpus 87.935/MG, Agravo Regimental no Habeas Corpus 423.838/SP, Habeas Corpus 438.147/SP, Habeas Corpus 461.194/TO, Habeas Corpus 448.036/RS, Habeas Corpus 470.307/SC.
}

Revista de Direito Brasileira | Florianópolis, SC | v. 23 | n. 9 | p. 364-388 | Mai./Ago. 2019 
presence of narcotic substances by Brazilian Superior Court, as it can be read in many of its decisions denying habeas corpus (BRASIL, 2012c, 2014d, 2015e, 20181, 2018k). ${ }^{12}$

But the indispensability of expert evidence is mitigated in cases of drunken driving, when the police presential examination by itself (without blood test or ethylometer) is enough to embase a criminal prosecution (BRASIL, 2016e, 2017m, 2017e, 2017b, 2017j, 2017d, 2017c, $2018 \mathrm{~b}) .{ }^{13}$

When analyzing decisions that dealt with the olfaction sense, it is interesting to notice that the referred Court considers that provoking accidents that occasion the loss of olfaction to the victims (which is proven, of course, by specialist evidencing) is a cause for civil liability mainly when the accident occurs between individuals (BRASIL, 2002). ${ }^{14}$ And the indemnity value varies between 80,000 and 30,000 reais (Brazilian currency) (BRASIL, 2011, 2016d). ${ }^{15}$

When the loss of olfaction is related to the indemnification recurring from the compulsory vehicle insurance (called "DPVAT" in Brazil), which is managed by a company called Seguradora Líder, which has national capital participation, not only the loss of the sense has to be detected: this loss has to be related to a permanent labour incapability to the victim (BRASIL, 2012b). ${ }^{16}$

But in demands related to the accident aid, a benefit paid by Brazilian Social Security, specialist evidencing has not only to testify that the loss of olfaction has occurred: this loss must be enough to put the plaintiff away permanently from work. This occurs in consequence of the Brazilian Statute of Social Security Benefits (Lei 8.213/1991) (BRASIL, 2016a). ${ }^{17}$

It is also interesting to notice that a Decree (Decreto 8.468/76) enforced by the São Paulo State, one of the most important in Brazilian Federation, was considered illegal by the Superior Court because it had adopted, as a standard for measurement of environmental pollution, the olfaction of accredited personnel. It was decided this way mainly because the Court understood that an administrative act (a decree) cannot impose a penalty (in case, a fee) because of a norm that lacks objectivity - in this case, the interpretation of an emission as being pollution or not because someone has used a sense (olfaction) that is entirely subjective (BRASIL, 2003, 1993). ${ }^{18}$

\section{CONCLUSION}

In order to conclude this work, it is important to point out that current science has shown that several conceptions about human olfactive capability has changed significantly. This sense, that is still used, sometimes, to make an opposition between the human an animal species, in fact, is much more potent and meaningful to human body, brain and communication than the scientific common sense has insinuated, at least, since the advent of Modernity.

\footnotetext{
${ }^{12}$ Recurso Ordinário em Habeas Corpus 29.483/MG, Habeas Corpus 296.256/SP, Recurso Ordinário em Habeas Corpus 52.561/MG, Recurso Ordinário em Habeas Corpus 98.951/PR, Recurso Ordinário em Habeas Corpus 98.397/MG.

${ }^{13}$ Recurso Ordinário em Habeas Corpus 69.856/SP, Recurso Ordinário em Habeas Corpus 73.589/DF, Agravo Regimental no Recurso Especial 1638451/RJ, Agravo Interno nos Embargos de Declaração no Agravo em Recurso Especial 769.140/DF, Recurso Especial 1684544/CE, Agravo Regimental no Habeas Corpus 340.161/PR, Agravo Regimental dos Embargos de Declaração no Habeas Corpus 354.810/PB, Agravo Regimental no Agravo em Recurso Especial 1226785/ES.

${ }^{14}$ Recurso Especial 404.706/SP.

${ }^{15}$ Agravo Regimental no Agravo de Instrumento 1392878/PR, Recurso Especial 1531096/PR.

${ }^{16}$ Agravo Regimental no Recurso Especial 1308294/MG.

${ }^{17}$ Agravo Interno no Agravo em Recurso Especial 875.457/SP.

${ }^{18}$ Recurso Especial 399.355/SP, Recurso Especial 35.887/SP.
}

Revista de Direito Brasileira | Florianópolis, SC | v. 23 | n. 9 | p 364-388 | Mai./Ago. 2019 
Scientific and other social considerations about smell and olfaction change historical and culturally - and this was shown during all the pages of this work. Perhaps the most significantly change of meaning on smell occurred during the modernity (understood as a contextually changing concept), when they gradually lost importance - in a way that was never scientifically true, despite all the rational pilots on which Western World has tried to show it structure. A rationality and a sociability built on instrumental reasoning and the sense of sight has imposed its predominance, but it can also be seen that they are not the only possible ones: alias, the more current use of rational observation in science has shown that.

After all this analysis, what can be observed in the jurisprudence of STJ, in first place, categorize olfaction as an important mean of communicating with the world, and also, as as important factor for characterizing human dignity in the environment. Law of Torts, Environment Law and Constitutional Law, when interpreted by STJ, enforce indemnifications, penalties and considerations about olfaction, often considering the disrespect of it as a significant illegality.

Olfaction is an important mean of evidencing, being used to detect the occurrence of illegalities - but perhaps in a biased way, as sometimes the lack of rationality affects the considerations about the official use of smell: for illicit drugs, trained dogs and specialist evidencing; for alcohol, the presence of authority feeling the smell of the substance in a subjective way.

But smell is also put in second place by the preconceptions of modernity that put sight, written language and specialist reason as being the most important sense, mean of communication and form of knowledge, respectively - in order to give decisions more juridical security and safeness. This does not mean, absolutely, that a return to precedent ways of reasoning and expressing are necessarily better or more adequate: the world of social affairs has reached a degree of complexity that puts the subjectivity of authority and the search for the spiritual essence of things in a position that cannot be considered as fundamental categories.

Nonetheless, the conceptions that human olfaction is a inferior sense is being largely debunked by science. The modern dogmas on which the modern rationality started to be erected must be reviewed not only in hard sciences, but also in social and human ones. And juridical conceptions must be part of this process of revision, as a provocative and irritating dialogue between Law and Sciences (regarding the most current facts discovered) must also substitute the instrumental authority that characterizes current legal orders around the world.

Obviously, there are limitations in this research: other Brazilian Courts should have their jurisprudence regarding to smell and olfaction studied, in order to confirm again the results of this work. And also, those results should be compared to the jurisprudence of other countries, in order to verify the constance of these finds. But it cannot be denied that these preliminary discoveries can provoke very rich future works in an unfortunately almost non explored transdisciplinary field, which is, law and the senses in Court decisions.

\section{REFERENCES}

BRASIL. Superior Tribunal de Justiça (2. Turma). Agravo Interno no Agravo em Recurso Especial 1207215/PR. [...] Estação de tratamento de esgoto. Emissão de mau cheiro. necessidade de apuração de fatos relevantes à solução da lide por meio de técnicos especializados (peritos). Revolvimento de material fático-probatório. Súmula 7/STJ [...]. rel. min. herman benjamin, 08 de maio de 2018a. Disponível em: https://ww2.stj.jus.br/processo/revista/documento/mediado/?componente=ATC\&sequencial=819 $33247 \&$ num_registro=201702950118\&data=20180802\&tipo=5\&formato=PDF. Acesso em: 02 maio 2019. 
BRASIL. Superior Tribunal de Justiça (2. Turma). Agravo Interno no Agravo em Recurso Especial 389.062/DF. [...] Aquisição de material de uso preventivo de doenças sexualmente transmissíveis (preservativos). Fornecimento de produto incompatível com as especificações previstas em edital. Inadequação ao uso. Efetivação do pagamento. Dano ao erário.

Ressarcimento. Deficiência na fundamentação. Súmula 284/STF. Dissídio jurisprudencial. alínea "c". Não demonstração da divergência. Matéria fático-probatória. incidência da súmula 7/stj [...]. Rel. Min. HERMAN BENJAMIN, 12 de agosto de 2014a. Disponível em:

https://ww2.stj.jus.br/processo/revista/documento/mediado/?componente=ITA\&sequencial=1337 661\&num_registro=201302899347\&data=20140925\&formato=PDF. Acesso em: 02 maio 2019.

BRASIL. Superior Tribunal de Justiça (2. Turma). Agravo Interno no Agravo em Recurso Especial 875.457/SP. [...] Auxílio-acidente. Perda do olfato e do paladar pela inalação de agentes químicos. Incapacidade laborativa. Não comprovada [...]. Rel. Min. HUMBERTO MARTINS, 19 de abril de 2016a. Disponível em:

https://ww2.stj.jus.br/processo/revista/documento/mediado/?componente=ITA\&sequencial=1505 087\&num_registro=201600542445\&data=20160426\&formato=PDF. Acesso em: 02 maio 2019.

BRASIL. Superior Tribunal de Justiça (3. Turma). Agravo Interno no Agravo em Recurso Especial 992.525/SP. [...] Descarrilamento de vagões transportando carga de enxofre e de cereais. demora excessiva para recolhimento da carga de enxofre cujo odor tornava insuportável. A permanência na via pública. responsabilidade. dano moral. revisão. valor. redução do quantum. Impossibilidade. Súmula 7/STJ. Multa do art. 538 do CPC/73. Afastamento. Impossibilidade. Súmula 7/STJ. Agravo desprovido. Rel. Min. PAULO de TARSO SANSEVERINO, 07 de novembro de 2017a. Disponível em:

https://ww2.stj.jus.br/processo/revista/documento/mediado/?componente=ITA\&sequencial=1652 804\&num_registro=201602589810\&data=20171110\&formato=PDF. Acesso em: 02 maio 2019.

BRASIL. Superior Tribunal de Justiça (2. Turma). Agravo Interno nos Embargos de Declaração no Agravo em Recurso Especial 769.140/DF. [...] Ação anulatória. Auto de infração de trânsito. Alegada ofensa ao art. 535 do CPC/73. Inexistência. Alegada violação ao princípio da identidade física do juiz. Inocorrência. Alegação de nulidade do auto de infração afastada, na origem. Controvérsia resolvida, pelo tribunal de origem, à luz das provas dos autos. Impossibilidade de revisão, na via especial. Súmula 7/STJ. Agravo interno improvido [...]. Rel. Min. ASSUSETE MAGALHÃes, 26 de setembro de 2017b. Disponível em: https://ww2.stj.jus.br/processo/revista/documento/mediado/?componente=ITA\&sequencial=1639 339\&num_registro=201502176781\&data=20171006\&formato=PDF. Acesso em: 02 maio 2019.

BRASIL. Superior Tribunal de Justiça (5. Turma). Agravo Regimental dos Embargos de Declaração no Habeas Corpus 354.810/PB. [...] Artigos 306, § 1o e 311 do CTB. Nulidade da ação penal. Desconsideração de depoimentos de testemunhas da defesa. Falsidade do laudo de constatação de alteração de sinais psicomotores. Violação à Súmula 11/STF. Supressão de instância. Inépcia da denúncia. Superveniência da sentença condenatória. Prejudicialidade. Artigo 306. Crime de perigo abstrato. Teste alveolar ou sanguíneo. Desnecessidade. Crime praticado após a lei n. 12.760/2012. Declarações de policiais. Validade [...]. Rel. Min. REYNALDO SOARES da FONSECA, 17 de outubro de 2017c. Disponível em: https://ww2.stj.jus.br/processo/revista/documento/mediado/?componente=ITA\&sequencial=1646 738\&num_registro=201601099592\&data=20171023\&formato=PDF. Acesso em: 02 maio 2019.

BRASIL. Superior Tribunal de Justiça (4. Turma). Agravo Regimental no Agravo de Instrumento 1392878/PR. [...] Perda do olfato e epilepsia pós-traumática decorrentes de 
acidente automobilístico. Dano moral. Valoração. Incidência da súmula 7/STJ. Agravo regimental desprovido [...]. Rel. Min. Raul Araújo, 18 de agosto de 2011. Disponível em: https://ww2.stj.jus.br/processo/revista/documento/mediado/?componente=ITA\&sequencial=1081 788\&num_registro=201100314486\&data=20110919\&formato=PDF. Acesso em: 02 maio 2019.

BRASIL. Superior Tribunal de Justiça (3. Turma). Agravo Regimental no Agravo em Recurso Especial 113.877/MS. [...] indenização por danos morais. conclusão do tribunal de origem firmada com base nas provas produzidas. revisão obstada. súmula STJ/7. Rel. Min. Sidnei Beneti, 19 de abril de 2012a. Disponível em:

https://ww2.stj.jus.br/processo/revista/documento/mediado/?componente=ITA\&sequencial=1140 816\&num_registro=201200198541\&data=20120503\&formato=PDF. Acesso em: 02 maio 2019.

BRASIL. Superior Tribunal de Justiça (5. Turma). Agravo Regimental no Agravo em Recurso Especial 1226785/ES. [...] Embriaguez ao volante. Violação do art. 155 do CPP. Inexistência. Súmula 568/STJ. Provas para condenação. Súmula 7/STJ. Agravo desprovido [...]. Rel. Min. REYNALDO SOARES DA FONSECA, 10 de abril de 2018b. Disponível em: https://ww2.stj.jus.br/processo/revista/documento/mediado/?componente=ITA\&sequencial=1696 627\&num_registro=201703339114\&data=20180418\&formato=PDF. Acesso em: 02 maio 2019.

BRASIL. Superior Tribunal de Justiça (2. Turma). Agravo Regimental no Agravo em Recurso Especial 401.510/RJ. [...] Falta de reparo em rede pública de esgoto sanitário. Ofensa ao art. 535 do CPC não configurada. Direito transindividual. Ampliação dos remédios jurídicos. Legitimidade concorrente [...]. Rel. Min. HERMAN BENJAMIN, 19 de abril de 2013 a. Disponível em: https://ww2.stj.jus.br/processo/revista/documento/mediado/?componente=ITA\&sequencial=1282 434\&num_registro=201303280076\&data=20131205\&formato=PDF. Acesso em: 02 maio 2019.

BRASIL. Superior Tribunal de Justiça (2. Turma). Agravo Regimental no Agravo em Recurso Especial 462.242/RJ. [...] Serviço público. Responsabilidade civil. Danos morais. Premissas fáticas. Impossibilidade de revisão. Súmula 7/STJ [...]. Rel. Min. HERMAN BENJAMIN, 27 de março de 2014b. Disponível em: https://ww2.stj.jus.br/processo/revista/documento/mediado/?componente=ITA\&sequencial=1309 906\&num_registro=201400072740\&data=20140422\&formato=PDF. Acesso em: 02 maio 2019.

BRASIL. Superior Tribunal de Justiça (2. Turma). Agravo Regimental no Agravo em Recurso Especial 622.639/SP. [...] Multa pela emissão de odores em atividade industrial. Ofensa ao art. 535 do CPC não configurada. Acórdão que se fundamentou em legislação local. Lei estadual 997/76 e Decreto estadual 8.468/76. Impossibilidade. Súmula 280/STF. Alteração do julgado. Inviabilidade. Súmula 7/STJ [...]. Rel. Min. HERMAN BENJAMIN, 17 de março de $2015 a$. Disponível em:

https://ww2.stj.jus.br/processo/revista/documento/mediado/?componente=ITA\&sequencial=1391 427\&num_registro=201403101554\&data=20150406\&formato=PDF. Acesso em: 02 maio 2019.

BRASIL. Superior Tribunal de Justiça (6. Turma). Agravo Regimental no Habeas Corpus 340.161/PR. [...] Crime de trânsito. Embriaguez. Materialidade delitiva. Indícios concretos. Inépcia da exordial acusatória não suficiente dos prosseguimento inexistência de regimental não provido [...]. Rel. Min. ROGERIO SCHIETTI CRUZ, 03 de abril de 2017d. Disponível em: https://ww2.stj.jus.br/processo/revista/documento/mediado/?componente=ITA\&sequencial=1642 017\&num_registro=201502763044\&data=20171009\&formato=PDF. Acesso em 02 maio 2019. 
BRASIL. Superior Tribunal de Justiça (6. Turma). Agravo Regimental no Habeas Corpus 423.838/SP. [...] Tráfico de drogas. Alegação da defesa de ilegalidade por invasão de domicílio. Ausência de constrangimento ilegal. Crime permanente. Forte odor de maconha. Nervosismo do paciente. Razão para realizar a busca no imóvel. Situação de flagrância. [...]. Rel. Min. SEBASTIÃO REIS JÚNIOR, 08 de fevereiro de 2018c. Disponível em: https://ww2.stj.jus.br/processo/revista/documento/mediado/?componente=ITA\&sequencial=1672 988\&num_registro=201702889166\&data=20180219\&formato=PDF. Acesso em: 02 maio 2019.

BRASIL. Superior Tribunal de Justiça (3. Turma). Agravo Regimental no Recurso Especial 1308294/MG. [...] Ação de cobrança. Seguro DPVAT. Perda do olfato. Incapacidade permanente. Súmula 7. Decisão Agravada. Manutenção [...]. Rel. Min. SIDNEI BENETI, julgado em 06 de dezembro de 2012b. Disponível em: https://ww2.stj.jus.br/processo/revista/documento/mediado/?componente=ITA\&sequencial=1201 008\&num_registro=201200220249\&data=20130204\&formato=PDF. Acesso em: 02 maio 2019.

BRASIL. Superior Tribunal de Justiça (2. Turma). Agravo Regimental no Recurso Especial 1346198/RJ. [...] Responsabilidade civil do estado. Violação do art. 535 do CPC. Ausência. Transbordamento de esgoto. Legitimidade ativa da pessoa lesada [...]. Rel. Min. Og Fernandes, 05 de agosto de 2014c. Disponível em:

https://ww2.stj.jus.br/processo/revista/documento/mediado/?componente=ITA\&sequencial=1335 331\&num_registro=201201604729\&data=20140814\&formato=PDF. Acesso em: 02 maio 2019.

BRASIL. Superior Tribunal de Justiça (2. Turma). Agravo Regimental no Recurso Especial 1560641/MG. [...] Responsabilidade civil da concessionária de serviço público. cadáver encontrado no reservatório de água. Acórdão de origem que, à luz da prova dos autos, concluiu que as alegações de deficiência na prestação do serviço e de omissão na segurança da área onde se encontrava o reservatório não restaram demonstradas, pelo que ausente o dano moral indenizável. Súmula 7/STJ. Agravo regimental improvido [...]. Rel. Min. Assusete Magalhães, 19 de novembro de 2015b. Disponível em:

https://ww2.stj.jus.br/processo/revista/documento/mediado/?componente=ITA\&sequencial=1467 612\&num_registro=201502560933\&data=20151202\&formato=PDF. Acesso em: 02 maio 2019.

BRASIL. Superior Tribunal de Justiça (6. Turma). Agravo Regimental no Recurso Especial 1638451/RJ. [...] Embriaguez ao volante. Delito de trânsito praticado após a lei no 12.760/12. Crime de perigo abstrato. Demonstração de potencialidade lesiva. Dispensabilidade. Aferição por etilômetro. Concentração de álcool maior que a permitida por lei [...]. Rel. Min. Maria Thereza de Assis Moura, 02 de maio de 2017e. Disponível em:

https://ww2.stj.jus.br/processo/revista/documento/mediado/?componente=ITA\&sequencial=1599 134\&num_registro=201603038430\&data=20170511\&formato=PDF. Acesso em: 02 maio 2019.

BRASIL. Superior Tribunal de Justiça (5. Turma). Habeas Corpus 296.256/SP. [...] Crimes de tráfico de drogas e associação para o tráfico. Prisão preventiva. Decisão fundamentada. Garantia da ordem pública. Constrangimento ilegal não configurado. 3. Condições pessoais favoráveis. Irrelevância [...]. Rel. Min. Marco Aurelio Bellizze, 19 de agosto de 2014d. Disponível em: https://ww2.stj.jus.br/processo/revista/documento/mediado/?componente=ITA\&sequencial=1340 889\&num_registro=201401336244\&data=20140827\&formato=PDF. Acesso em: 02 maio 2019.

BRASIL. Superior Tribunal de Justiça (5. Turma). Habeas Corpus 305.308/SP. [...] Tráfico de entorpecentes. Associação para o tráfico. Prisão preventiva. Garantia da ordem pública. 
Quantidade e grau de nocividade da substância apreendida. Prisão que visa obstar a continuidade delitiva. Segregação cautelar devidamente fundamentada. [...]. Rel. Min. Felix Fischer, 10 de fevereiro de 2015c. Disponível em:

https://ww2.stj.jus.br/processo/revista/documento/mediado/?componente=ITA\&sequencial=1381 945\&num_registro=201402475980\&data=20150227\&formato=PDF. Acesso em: 02 maio 2019.

BRASIL. Superior Tribunal de Justiça (5. Turma). Habeas Corpus 337.247/SP. [...] Tráfíco de drogas. Irregularidades na prisão em flagrante. Superveniência de prisão preventiva. Tese superada. Segregação cautelar. Garantia da ordem pública. Fundamentação idônea. Ausência de provas. Reexame fático-probatório. Inviabilidade [...]. Rel. Min. Gurgel De Faria, 24 de novembro de 2015d. Disponível em: https://ww2.stj.jus.br/processo/revista/documento/mediado/?componente=ITA\&sequencial=1469 998\&num_registro=201502437742\&data=20151217\&formato=PDF. Acesso em: 02 maio 2019.

BRASIL. Superior Tribunal de Justiça (5. Turma). Habeas Corpus 364.024/SC. [...] Tráfico de drogas e absolvição. Alegação que enseja aprofundado reexame de prova. Impossibilidade pela via estrita do writ. Dosimetria da pena. Penas-base fixadas acima do mínimo legal.

Fundamentação idônea. Aplicação da minorante prevista no § 4o do art. 33 da lei n. 11.343/06. Substituição da pena privativa de liberdade por restritiva de direitos. Impossibilidade [...]. Rel. Min. Felix Fischer, 22 de novembro de 2016b. Disponível em: https://ww2.stj.jus.br/processo/revista/documento/mediado/?componente=ITA\&sequencial=1556 415\&num_registro=201601941271\&data=20161130\&formato=PDF. Acesso em: 02 maio 2019.

BRASIL. Superior Tribunal de Justiça (5. Turma). Habeas Corpus 378.323/SC. [...] Tráfico de entorpecentes. Alegação de nulidade do flagrante, por inobservância da garantia constitucional da inviolabilidade de domicílio. Inocorrência. Tráfico. Crime permanente. Fundadas razões para a entrada forçada no domicílio. Pretensão que demanda o revolvimento do material fáticoprobatório dos autos. Impossibilidade na via eleita. Habeas corpus não conhecido [...]. Rel. Min. Felix Fischer, 06 de abril de 2017f. Disponível em:

https://ww2.stj.jus.br/processo/revista/documento/mediado/?componente=ITA\&sequencial=1589 623\&num_registro=201602963141\&data=20170425\&formato=PDF. Acesso em: 02 maio 2019.

BRASIL. Superior Tribunal de Justiça (5. Turma). Habeas Corpus 379.479/SP. [...] Divulgação e armazenamento de pornografia infantil (arts. 241-a e 241-b do ECA). Prisão preventiva. Preenchimento dos requisitos. Gravidade concreta do delito. Periculosidade do agente. Perniciosidade da conduta. Fundamentação idônea. Condições pessoais favoráveis. Irrelevância. Medidas cautelares do art. 319 do CPP. Inviabilidade. Coação ilegal não demonstrada. Ordem não conhecida [...]. Rel. Min. REYNALDO SOARES da FONSECA, 20 de abril de 2017g. Disponível em:

https://ww2.stj.jus.br/processo/revista/documento/mediado/?componente=ITA\&sequencial=1592 573\&num_registro=201603056022\&data=20170427\&formato=PDF. Acesso em: 02 maio 2019.

BRASIL. Superior Tribunal de Justiça (6. Turma). Habeas Corpus 409.361/AM. [...] Art. 54, § 2o, V, e art. 60, c/c os arts. 2o e 3o, todos da lei n. 9.605/1998, na forma dos arts. 29 e 69 do Código Penal. Inépcia da denúncia. Não ocorrência. Ordem denegada [...]. Rel. Min. Antonio Saldanha Palheiro, 21 de junho de 2018d. Disponível em: https://ww2.stj.jus.br/processo/revista/documento/mediado/?componente=ITA\&sequencial=1727 691\&num_registro=201701801219\&data=20180802\&formato=PDF. Acesso em: 02 maio 2019. 
BRASIL. Superior Tribunal de Justiça (6. Turma). Habeas Corpus 415.574/MG. [...] Tráfico de drogas. Prisão preventiva. Art. 312 do CPP. Fumus comissi delicti. Periculum libertatis. Natureza e expressiva quantidade da droga. Reiteração delitiva. Fundamentação suficiente. Ordem denegada [...]. Rel. Min. Rogerio Schietti Cruz, 14 de novembro de 2017h. Disponível em: https://ww2.stj.jus.br/processo/revista/documento/mediado/?componente=ITA\&sequencial=1655 055\&num_registro=201702302182\&data=20171121\&formato=PDF. Acesso em: 02 maio 2019.

BRASIL. Superior Tribunal de Justiça (5. Turma). Habeas Corpus 438.147/SP. [...] Tráfico de drogas. Prisão em flagrante. Invasão de domicílio. Presença de justa causa. Prisão preventiva. Necessidade de garantia da ordem pública. Constrangimento ilegal não caracterizado. Habeas corpus não conhecido [...]. Rel. Min. Ribeiro Dantas, 22 de maio de 2018e. Disponível em: https://ww2.stj.jus.br/processo/revista/documento/mediado/?componente=ITA\&sequencial=1714 992\&num_registro=201800415777\&data=20180530\&formato=PDF. Acesso em: 02 maio 2019.

BRASIL. Superior Tribunal de Justiça (5. Turma). Habeas Corpus 442.556/RJ. [...] Tráfico ilícito de entorpecentes. Prisão preventiva. Preenchimento dos requisitos. Ausência de motivação concreta. Fundamentação inidônea. Quantidade não expressiva de droga. Constrangimento ilegal configurado. Habeas corpus não conhecido. Ordem concedida de ofício. Medidas alternativas pertinentes [...]. Rel. Min. Reynaldo Soares Da Fonseca, 17 de abril de 2018f. Disponível em: https://ww2.stj.jus.br/processo/revista/documento/mediado/?componente=ITA\&sequencial=1699 069\&num_registro=201800688585\&data=20180425\&formato=PDF. Acesso em: 02 maio 2019.

BRASIL. Superior Tribunal de Justiça (6. Turma). Habeas Corpus 448.036/RS. [...] Tráfico de drogas e associação para o tráfico. Prisão preventiva. Fundamentação concreta. Ilegalidade. Ausência. Aplicação de medidas alternativas à prisão. Insuficiência à garantia da ordem pública. Extensão de efeitos de ordem concedida à corré. Não cabimento. Ausência de identidade fáticoprocessual. Habeas corpus denegado [...]. Rel. Min. Nefi Cordeiro, 18 de setembro de 2018g. Disponível em:

https://ww2.stj.jus.br/processo/revista/documento/mediado/?componente=ITA\&sequencial=1752 944\&num_registro=201801011118\&data=20181001\&formato=PDF. Acesso em: 02 maio 2019.

BRASIL. Superior Tribunal de Justiça (5. Turma). Habeas Corpus 461.194/TO. [...] Tráfico de drogas e associação para o tráfico. Prova da materialidade do delito. Ausência de laudo toxicológico definitivo. Possibilidade excepcional de comprovação da materialidade do delito por laudo de constatação provisório assinado por perito. Associação para o tráfico. Estabilidade e permanência. Elementos demonstrados no acórdão impugnado. [...]. Rel. Min. Reynaldo Soares da Fonseca, 20 de setembro de 2018h. Disponível em:

https://ww2.stj.jus.br/processo/revista/documento/mediado/?componente=ITA\&sequencial=1753 510\&num_registro=201801869259\&data=20181001\&formato=PDF. Acesso em: 02 maio 2019.

BRASIL. Superior Tribunal de Justiça (6. Turma). Habeas Corpus 470.307/SC. [...] Tráfico de drogas. Flagrante. Domicílio como expressão do intimidade. Asilo inviolável. Constitucionais. Interpretação invasão de domicílio pela polícia. Justa causa configurada. Posse ilegal de arma de fogo. Absolvição. Laudo pericial juntado após a sentença. Prescindibilidade da prova. Ordem denegada [...]. Rel. Min. Rogerio Schietti Cruz, 09 de outubro de 2018i. Disponível em: https://ww2.stj.jus.br/processo/revista/documento/mediado/?componente=ITA\&sequencial=1761 228\&num_registro=201802457736\&data=20181029\&formato=PDF. Acesso em: 02 maio 2019.

BRASIL. Superior Tribunal de Justiça (2. Turma). Recurso em Mandado de Segurança 46.701/MG. [...] Decisão limitando a capacidade de presídio local com fundamento no art. 66, 
VII e VIII, da LEP. Superlotação de presídio. Condições precárias. Ofensa ao princípio da dignidade da pessoa humana. Violação ao princípio da separação de poderes. Não ocorrência [...]. Rel. Min. Herman Benjamin, 05 de maio de 2016c. Disponível em: https://ww2.stj.jus.br/processo/revista/documento/mediado/?componente=ITA\&sequencial=1509 821\&num_registro=201402595806\&data=20160525\&formato=PDF. Acesso em: 02 maio 2019.

BRASIL. Superior Tribunal de Justiça (3. Turma). Recurso Especial 1531096/PR. [...] Responsabilidade civil. Acidente de trânsito. Danos materiais, morais e estéticos. Pensionamento mensal. Indenização. Majoração. Súmula no 7/STJ. Dissídio não configurado. Artigo 950, parágrafo único, do Código Civil. Pagamento em única parcela. Manutenção do acórdão. Súmula no 7/STJ [...]. Rel. Min. Ricardo Villas Bôas CUEVA, 17 de maio de 2016d. Disponível em: https://ww2.stj.jus.br/processo/revista/documento/mediado/?componente=ITA\&sequencial $=1512$ 630\&num_registro=201402703856\&data=20160523\&formato=PDF. Acesso em: 02 maio 2019.

BRASIL. Superior Tribunal de Justiça (2. Turma). Recurso Especial 1653359/MG. [...] Procedimento administrativo para apuração de irregularidades em entidade de atendimento. Tutela liminar específica de obrigação de fazer, com multa cominatória. estipulação de prazo para apresentação de projeto de correção das irregularidades, especificando as ações necessárias e o cronograma de execução. Legalidade. Art. 193, § 3o, do ECA, c/c arts. 152 do mesmo diploma legal. [...]. Rel. Min. Herman Benjamin, 19 de outubro de 2017i. Disponível em: https://ww2.stj.jus.br/processo/revista/documento/mediado/?componente=ITA\&sequencial=1592 322\&num_registro=201700278908\&data=20180201\&formato=PDF. Acesso em: 02 maio 2019.

BRASIL. Superior Tribunal de Justiça (2. Turma). Recurso Especial 1684544/CE. [...] Dirigir sob a influência de álcool. Reexame do conjunto fático-probatório. Impossibilidade. Súmula 7/STJ [...]. Rel. Min. Herman Benjamin, 21 de setembro de 2017j. Disponível em: https://ww2.stj.jus.br/processo/revista/documento/mediado/?componente=ITA\&sequencial=1637 970\&num_registro=201701535983\&data=20171009\&formato=PDF. Acesso em: 02 maio 2019.

BRASIL. Superior Tribunal de Justiça (2. Turma). Recurso Especial 1693951/RS. [...] Indenização. Instalação de estação de tratamento de esgoto. Mau cheiro. Recorrentes residentes fora da área de zoneamento estipulado pelo MP. Impossibilidade de averiguação de possíveis danos. Súmula 7/STJ [...]. Rel. Min. Herman Benjamin, 17 de outubro de 2017k. Disponível em: https://ww2.stj.jus.br/processo/revista/documento/mediado/?componente=ITA\&sequencial=1648 134\&num_registro=201700948621\&data=20171023\&formato=PDF. Acesso em: 02 maio 2019.

BRASIL. Superior Tribunal de Justiça (2. Turma). Recurso Especial 1718176/RS. Processual civil. Juros de mora. Termo inicial. Data do evento danoso. Súmula 54 do STJ [...]. Rel. Min. Herman Benjamin, 1o. de março de 2018j. Disponível em:

https://ww2.stj.jus.br/processo/revista/documento/mediado/?componente=ITA\&sequencial=1682 100\&num_registro=201800049525\&data=20180802\&formato=PDF. Acesso em: 02 maio 2019.

BRASIL. Superior Tribunal de Justiça (1. Turma). Recurso Especial 32.103/SP. [...] Não é ilegal o regulamento (Decreto Estadual n. 8.468) que se constringe dentro dos limites que podia atuar, sem instituir nova infração (e nem obrigação diferente), ao disciplinar os padrões de qualidade ambiental, observadas a intensidade, a concentração, a quantidade e as características de toda e qualquer forma de matéria e energia. O regulamento proíbe a emissão de odor perceptível, fora das fronteiras da propriedade da fonte emissora e a quantificação e intensidade desses odores, "in casu", foram aferidos por peritos especializados, em laudos com exuberante motivação, justificando a multa aplicada [...]. Rel. Min. Demócrito Reinaldo, 07 de dezembro de 
1994. Disponível em:

https://ww2.stj.jus.br/processo/ita/documento/mediado/?num_registro=199300033190\&dt_public acao=20-02-1995\&cod_tipo_documento=. Acesso em: 02 maio 2019.

BRASIL. Superior Tribunal de Justiça (1. Turma). Recurso Especial35.887/SP. [...] O Decreto 8.468/76 do Estado de S. Paulo - quando adotou como padrões de medida de poluição ambiental, a extensão da propriedade e o olfato de pessoas credenciadas - incidiu em ilegalidade, contrariando o sistema erigido na Lei Federal 6.938/81. Rel. Min. Garcia Vieira, 22 de novembro de 1993. Disponível em:

https://ww2.stj.jus.br/processo/ita/documento/mediado/?num_registro=199300163833\&dt_public acao=07-02-1994\&cod_tipo_documento=. Acesso em: 02 maio 2019.

BRASIL. Superior Tribunal de Justiça (1. Turma). Recurso Especial 399.355/SP. [...] O Decreto 8.468/76 do Estado de São Paulo, incidiu em ilegalidade, contrariando o sistema erigido na Lei Federal 6.938/81, quando adotou como padrões de medida de poluição ambiental, a extensão da propriedade e o olfato de pessoas credenciadas. Rel. Min. HUMBERTO GOMES de BARROS, 11 de novembro de 2003. Disponível em:

https://ww2.stj.jus.br/processo/revista/documento/mediado/?componente=ITA\&sequencial=4415 83\&num_registro=200101968980\&data=20031215\&formato=PDF. Acesso em: 02 maio 2019.

BRASIL. Superior Tribunal de Justiça (4. Turma). Recurso Especial 404.706/SP. [...] A perda do olfato e do paladar é causa de incapacidade que atinge gravemente a pessoa, prejudica sua vida de relação, impede-a de usufruir de alguns prazeres da vida e mesmo prejudica a defesa da sua saúde, o que exige indenização compatível. Recurso conhecido e provido em parte para deferir verba indenizatória equivalente a 400 salários mínimos. Rel. Min. RUY ROSADO de AGUIAR, 27 de junho de 2002. Disponível em:

https://ww2.stj.jus.br/processo/revista/documento/mediado/?componente=ITA\&sequencial=1079 87\&num_registro=200200037539\&data=20020902\&formato=PDF. Acesso em: 02 maio 2019.

BRASIL. Superior Tribunal de Justiça (1. Turma). Recurso Especial 693.172/MG. [...] Indenização por danos morais. Culpa exclusiva da vítima. Redução do quantum indenizatório. Matéria fático-probatória. Súmula n. ${ }^{\circ}$ 07/STJ [...]. Rel. Min. Luiz Fux, 23 de agosto de 2005. Disponível em:

https://ww2.stj.jus.br/processo/revista/documento/mediado/?componente $=$ ITA\&sequencial=5726 67\&num_registro=200401387295\&data=20050912\&formato=PDF. Acesso em: 02 maio 2019.

BRASIL. Superior Tribunal de Justiça (1. Turma). Recurso Especial 840.011/PR. [...] Ação civil pública. Dano ao meio ambiente. Bacia hidrográfica envolvida pelo desenvolvimento urbano. Área de preservação ambiental permanente. Lago artificial. Determinação de aterramento parcial. Urbanização e saneamento. Necessidade imposta pela ocupação humana. Medida de proteção à saúde da população. Prova. Alteração ambiental que atingiu apenas parte da bacia. Prevalência daqueles valores. Opção administrativa. Conjuntura de fato. Súmula 07/STJ. Ofensa ao art. 535, do CPC. Inexistência [...]. Rel. Min. Luiz Fux, 20 de setembro de 2007. Disponível em:

https://ww2.stj.jus.br/processo/revista/documento/mediado/?componente=ITA\&sequencial=7226 58\&num_registro=200600597046\&data=20071008\&formato=PDF. Acesso em: 02 maio 2019.

BRASIL. Superior Tribunal de Justiça (5. Turma). Recurso Ordinário em Habeas Corpus 29.483/MG. [...] Tráfico de entorpecentes (artigo 33, caput, da lei 11.343/2006). Alegada nulidade da prisão do recorrente. Flagrante que teria sido forjado pelos policiais responsáveis 
pela localização da droga. Constrangimento ilegal não caracterizado. Desprovimento do recurso [...]. Rel. Min. Jorge Mussi, 02 de outubro de 2012c. Disponível em:

https://ww2.stj.jus.br/processo/revista/documento/mediado/?componente=ITA\&sequencial=1183 555\&num_registro=201002230655\&data=20121009\&formato=PDF. Acesso em: 02 maio 2019.

BRASIL. Superior Tribunal de Justiça (5. Turma). Recurso Ordinário em Habeas Corpus 34.981/PR. [...] Tráfico internacional de drogas. Prisão em flagrante convertida em custódia preventiva. Fundamentação idônea. Constrangimento ilegal não evidenciado. Recurso desprovido [...]. Rel. Min. Laurita Vaz, 26 de fevereiro de 2013b. Disponível em:

https://ww2.stj.jus.br/processo/revista/documento/mediado/?componente=ITA\&sequencial=1212 082\&num_registro=201202748443\&data=20130306\&formato=PDF. Acesso em: 02 maio 2019.

BRASIL. Superior Tribunal de Justiça (5. Turma). Recurso Ordinário em Habeas Corpus 52.561/MG. [...] Tráfico de entorpecentes. Associação para o tráfico. Corrupção de menores. Prisão preventiva. Garantia da ordem pública. Quantidade e grau de nocividade das substâncias apreendidas. Constrangimento ilegal. Ausência de fundamentação. Periculosidade. Modus operandi. Segregação cautelar devidamente fundamentada. Recurso ordinário desprovido [...]. Rel. Min. Felix Fischer, 03 de março de 2015e. Disponível em: https://ww2.stj.jus.br/processo/revista/documento/mediado/?componente=ITA\&sequencial=1387 178\&num_registro=201402628224\&data=20150326\&formato=PDF. Acesso em: 02 maio 2019.

BRASIL. Superior Tribunal de Justiça (5. Turma). Recurso Ordinário em Habeas Corpus 63.357/PA. [...] Crime ambiental (art. 54, $\S 1$ o e 2o, inciso II da lei 9.605/98. Trancamento da ação penal. Excepcionalidade na via do writ. Denúncia que preenche os requisitos do art. 41 do CPP. Atipicidade. Crime formal, de perigo abstrato. Carência de adequação típica para a persecução penal. Laudo genérico. Necessidade de revolvimento fático-probatório. Impossibilidade. Recurso não provido [...]. Rel. Min. Ribeiro Dantas, julgado em 27 de junho de 20171. Disponível em:

https://ww2.stj.jus.br/processo/revista/documento/mediado/?componente=ITA\&sequencial=1616 543\&num_registro=201502119935\&data=20170801\&formato=PDF. Acesso em: 02 maio 2019.

BRASIL. Superior Tribunal de Justiça (5. Turma). Recurso Ordinário em Habeas Corpus 69.856/SP. [...] Embriaguez ao volante. Trancamento do processo-crime. Excepcionalidade. Falta de justa causa para a persecução penal. Necessidade de revolvimento fático-comprobatório. Inviabilidade na via eleita. Materialidade delitiva. Alteração da capacidade psicomotora comprovada por prova testemunhal, perícia e teste de etilômetro. Crime praticado após o advento da lei n. 12.760/2012. Recurso desprovido [...]. Rel. Min. Ribeiro Dantas, 22 de novembro de 2016e. Disponível em:

https://ww2.stj.jus.br/processo/revista/documento/mediado/?componente=ITA\&sequencial=1556 745\&num_registro=201601029631\&data=20161125\&formato=PDF. Acesso em: 02 maio 2019.

BRASIL. Superior Tribunal de Justiça (5. Turma). Recurso Ordinário em Habeas Corpus 73.589/DF. [...] Admissão da comprovação do estado de embriaguez por qualquer meio de prova. Inexistência de prova tarifada no art. 306, § 2o, da lei no 9.503/97. Recurso ao qual se nega provimento [...]. Rel. Min. Joel Ilan Paciornik, 21 de fevereiro de 2017m. Disponível em: https://ww2.stj.jus.br/processo/revista/documento/mediado/?componente=ITA\&sequencial=1573 753\&num_registro=201601916965\&data=20170306\&formato=PDF. Acesso em: 02 maio 2019.

BRASIL. Superior Tribunal de Justiça (6. Turma). Recurso Ordinário em Habeas Corpus 87.935/MG. [...] Tráfico e associação para o tráfico de drogas. Prisão preventiva. Fundamentos 
concretos. Necessidade de garantia da ordem pública. Constrangimento ilegal não caracterizado. Recurso desprovido [...]. Rel. Min. Sebastião Reis Júnior, 19 de setembro de 2017n. Disponível em:

https://ww2.stj.jus.br/processo/revista/documento/mediado/?componente=ITA\&sequencial=1635 881\&num_registro=201701947237\&data=20170927\&formato=PDF. Acesso em: 02 maio 2019.

BRASIL. Superior Tribunal de Justiça (5. Turma). Recurso Ordinário em Habeas Corpus 98.397/MG. [...] Tráfico de drogas. Prisão preventiva. Fundamentação. Gravidade concreta. Periculosidade social (apreensão de maconha, cocaína e crack). Risco de reiteração. Necessidade de garantia da ordem pública. Recurso desprovido [...]. Rel. Min. Reynaldo Soares Da Fonseca, 16 de outubro de 2018k. Disponível em: https://ww2.stj.jus.br/processo/revista/documento/mediado/?componente=ITA\&sequencial=1762 869\&num_registro=201801201125\&data=20181026\&formato=PDF. Acesso em: 02 maio 2019.

BRASIL. Superior Tribunal de Justiça (5. Turma). Recurso Ordinário em Habeas Corpus 98.951/PR. [...] Tráfico ilícito de entorpecentes. Prisão preventiva. Preenchimento dos requisitos. Ausência de motivação concreta. Fundamentação inidônea. Quantidade não expressiva de droga. Constrangimento ilegal configurado. Parecer ministerial pelo provimento. Recurso provido. Medidas alternativas pertinentes [...]. Rel. Min. Reynaldo Soares Da Fonseca, 07 de agosto de 20181. Disponível em: e. Acesso em: 02 maio 2019.

BURTON, Robert. The language of smell. London, Henley and Boston: Routledge \& Kegan Paul, 1976.

CHADWICK, M. J. et. al. Semantic representations in the temporal pole predict false memories. Proceedings of The National Academy ofSciences, v. 113, p. 10180-10185,2016

CLASSEN, Constance. Worlds of sense: exploring the senses in history and across cultures. London: Routledge, 1993.

CLASSEN, Constance; HOWES, David; SYNNOTT, Anthony. Aroma: the Cultural History of Smell. London; New York: Routledge, 1994.

CONDILLAC, E. B. de. Condillac's treatise on the sensations. Translated by M. G. S. Carr. London: The Favil Press, 1930 (Original work published 1754).

CORBIN, Alain. Le miasme et la jonquille: l'odorat et l'imaginaire social: XVIIIe-XIXesiècles. Paris: Flammarion, 2008 (1982).

DARWIN, Charles. The descent of man, and selection in relation to sex. London: John Murray, 1874.

DE BRUIJN, Maaike J.; BENDER, Michael. Olfactory cues are more effective than visual cues in experimentally triggering autobiographical memories. Memory, v. 26, n. 4, p. 547-558, 2018.

DEGEL, Joachim. Implicit odor memory. Utrecht: Universiteit Utrecht, 2000.

DROBNICK, Jim. Volatile effects: olfactory dimensions of art and architecture. In: HOWES, David (ed.). Empire senses: the sensual culture reader. Oxford; New York, 2005, p. 265-280. 
ENGEN, Trygg. Odor sensation and memory. New York, Westport and London: Praeger, 1989.

HALPERN, M; MARTINEZ-MARCOS, A. Structure and function of the vomeronasal system: an update. Progress in Neurobiology, v. 70, I. 03, p. 245-318, 2003. Disponível em:

https://www.ncbi.nlm.nih.gov/pubmed/12951145. Acesso em: 02 maio 2019.

HOWES, David. El creciente campo de los Estudios Sensoriales. Revista Latinoamericana de Estudios sobre Cuerpos, v. 2, n. 15, p.10-26, 2014. Disponível em:

http://www.relaces.com.ar/index.php/relaces/article/viewArticle/330. Acesso em: 02 maio 2019.

HOWES, David; CLASSEN, Constance. Ways of sensing: understanding the senses in society. London; New York: Routledge, 2014.

KANT, Immanuel. Anthropology from a pragmatic point of view. Translated by R. B. Louden. Cambridge: Cambridge University Press, 2006. (Original work published 1798).

LASKA, Mathias.; MIETHE, Vera; RIECK, Cornelia; WEINDL, Karin. Olfactory sensitivity for aliphatic ketones in squirrel monkeys and pigtail macaques. Experimental Brain Research, v. 160, n. 3, p. 302-311, 2005. Disponível em: https://link.springer.com/article/10.1007\%2Fs00221004-2012-0. Acesso em: 02 maio 2019.

LASKA, Mathias; SEIBT, Alexandra; WEBER Andreas. 'Microsmatic' Primates Revisited: Olfactory Sensitivity in the Squirrel Monkey. Chemical Senses, v. 25, n. 1, p. 47-53, 2000. Disponível em: https://academic.oup.com/chemse/article/25/1/47/345710. Acesso em: 02 maio 2019.

LE GUÉRER, Annick. Scent: the mysterious and essential powers of smell. Translated from the French by Richard Miller. London: Chatto \& Windus, 1993.

LOBMAIER, J. S.; FISCHBCHER, U.; WIRTHMÜLLER, U.; KNOCH, D. The scent of attractiveness: levels of reproductive hormones explain individual differences in women's body odour. Proceedings of the Royal Society B, v. 285, n. 1886, p. 15-20, 2018. Disponível em: https://royalsocietypublishing.org/doi/abs/10.1098/rspb.2018.1520. Acesso em: 02 maio 2019.

LUHMANN, Niklas. A restituição do décimo segundo camelo: do sentido de uma análise sociológica do direito. In: ARNAUD, André-Jean; LOPES JR, Dalmir (Orgs.). Niklas Luhmann: do sistema social à sociologia jurídica. Trad. Dalmir Lopes Jr., Daniele Andréa da Silva Manão e Flávio Elias Riche. Rio de Janeiro: Lúmen Júris, 2004, p. 33-107.

LUHMANN, Niklas. Law as a social system. New York: Oxford University Press, 2004.

LUHMANN, Niklas. Law as a social system. Northwestern University Law Review, v. 83, n. 1-2, p. 136-150, 1988-1989.

LUHMANN, Niklas. Organización y decisión. Autopoiesis, acción y entendimiento comunicativo. Trad. Darío Rodríguez Mansilla. Barcelona: Anthropos; México: Universidad Iberoamericana; Santiago de Chile: Instituto de Sociologia da Pontifícia Universidad Católica de Chile, 2005. 
LUHMANN, Niklas. Self-reproduction of Law and Its Limits In LUHMANN, Niklas. Essays on Self-Reference. New York: Columbia University Press, 1990, p. 227-254.

LUHMANN, Niklas. Social systems. Translated by John Bednarz Jr and Dirk Baecker. Stanford: Stanford University Press, 1995.

MACGANN, John P. Poor human olfaction is a 19th century myth. Science, v. 356, i. 6338, eaam 7213, 12 may 2017. Disponível em: https://science.sciencemag.org/content/356/6338/eaam7263. Acesso em: 02 maio 2019.

MAJID, Asifa; BURENHULT, Niclas. Odors are expressible in language, as long as you speak the right language. Cognition, v. 130, i. 02, p. 266-270,February 2014. Disponível em: https://www.sciencedirect.com/science/article/pii/S001002771300214X?via\%3Dihub. Acesso em: 02 maio 2019.

MAJID, Asifa et al. Olfactory language and abstraction across cultures. Philosophical Transactions of Royal Society B, vol. 373, p. 1-8,18 June 2018. Disponível em: https://royalsocietypublishing.org/doi/pdf/10.1098/rstb.2017.0139. Acesso em: 02 maio 2019.

MAJID, Asifa; KRUSPE, Nicole Kruspe. Hunter-Gatherer Olfaction is Special. Current Biology, vol. 28, p. 409-413, 2018. Disponível em: https://reader.elsevier.com/reader/sd/pii/S0960982217316160?token=8C86783F68E9AA49FAB9 84129FB9FBAF9FB0886834B1CA945CAF151DAA1D3258814E5982B154D35FD3AC2C0374 57596B. Acesso em: 02 maio 2019.

MARTIN, G. Neil. The Neuropsychology of Smell and Taste. London; New York: Psychology Press, 2013.

MARUSEK, Sarah. Reasonable or Offensive? Smell, Jurisdiction, and Public Right In: MANDIC, Danilo; NIRTA, Caterina; PAVONI, Andrea; PHILIPPOPOULOSMIHALOPOULOS, Andreas (ed.). Non Liquet: The Westminster Online Working Papers Series, Law and the Senses Series: The Smell Issue, 2015, 32-41.

ONG, Walter. The presence of the word: some prolegomena for cultural and religious story. New Haven: Yale University Press, 1967.

ORWELL, George. The Road to Wigan Pier. London: Victor Gollancz, 1937.

PEREIRA, Henrique Mioranza Koppe; SIMIONI, Rafael Lazzarotto. A decisão jurídica em Niklas Luhmann: operação, diferença e abertura. Anais do XVIII Congresso Nacional do CONPEDI, São Paulo, 04 a 07 de novembro de 2009, p. 6499-6513. Disponível em: http://www.publicadireito.com.br/conpedi/manaus/arquivos/Anais/sao_paulo/2261.pdf. Acesso em: 03 maio 2019, p. 6506.

PORTER, R. H.; CERNOCH, J. M.; MACLAUGHLIN, F. J. Maternal recognition of neonates through olfactory cues. Psychology and behavior, v. 30, i. 01, p. 151-154, 1983. Disponível em: https://www.sciencedirect.com/science/article/abs/pii/0031938483900513. Acesso em: 02 maio 2019. 
SAIVE, A.-L.;ROYET, J.-P.;PLAILLY,, J. A review on the neural bases of episodic odor memory: From laboratory-based to autobiographical approaches. Frontiers in Behavioral Neuroscience, v. 8, 07 July 2014. Disponível em:

https://www.frontiersin.org/articles/10.3389/fnbeh.2014.00240/full. Acesso em: 02 maio 2019.

SCHAAL, Benoist; PORTER, Richard. "Microsmatic Humans" Revisited: The Generation and Perception of Chemical Signals. Advances in the Study of Behavior, v. 20, p. 135-199, December 1991. Disponível em: https://www.sciencedirect.com/science/article/pii/S0065345408603216. Acesso em: 02 maio 2019.

SHAW, Barney. The smell of fresh rain: the unexpected pleasures of our most elusive sense. London: Icon Books, 2017.

SHEPHERD, Gordon M. The human sense of smell: Are we better than we think? PLOS Biology,v. 2, i. 5, p. 572-575, 2004. Disponível em: https://journals.plos.org/plosbiology/article?id=10.1371/journal.pbio.0020146. Acesso em: 02 maio 2019.

SMITH, Mark M. Transcending, othering, detecting: smell, premodernity, modernity. Postmedieval: a Journal of Medieval Cultural Studies, vol. 3, i. 4, p. 380-390, 07 December 2012. Disponível em: https://link.springer.com/article/10.1057/pmed.2012.35. Acesso em: 02 maio 2019.

SULLIVAN, R. M.; TOUBAS, P. Clinical usefulness of maternal odor in newborns:soothing and feeding preparatory responses. Biology of the neonate, v. 74, p. 402-408, 1998. Disponível em: https://www.karger.com/Article/Abstract/14061. Acesso em: 02 maio 2019.

SYNNOTT, Anthony. A sociology of smell. Canadian Review of Sociology and Anthropology, v. 28, n. 4, p. 437-459,November 1991. Disponível em: https://onlinelibrary.wiley.com/doi/abs/10.1111/j.1755-618X.1991.tb00164.x. Acesso em: 02 maio 2019.

SYNNOTT, Anthony. Puzzling over the senses: from Plato to Marx In HOWES, David (ed.). The varieties of sensory experience: a sourcebook in anthropology of the senses. Toronto: University of Toronto Press, 1991.

TAMMINES, Jakke; MEBUDE, Mariam. Reinstatement of odour context cues veridical memories but not false memories. Memory, august 2018. Disponível em: https://www.tandfonline.com/doi/full/10.1080/09658211.2018.1513041. Acesso em: 02 maio 2019.

TEUBNER, Gunther. Introduction to Autopoietic Law In TEUBNER Gunther (ed.). Autopoietic Law: a new approach to Law and Society (Conference) (1987: Florence, Italy) Berlin; New York: W. de Gruyter, 1987, p. 1-11.

TULLETT, William. Grease and Sweat: Race and Smell in Eighteenth-Century English Culture. Cultural and Social History, vol. 13, n. 3, p. 307-322, 2016. Disponível em: https://tandfonline.com/doi/full/10.1080/14780038.2016.1202008. Acesso em: 02 maio 2019. 
VROON, Piet; AMERONGEN, Anton von; VRIES, Hans de. Smell: the secret seducer. Translated from the Dutch by Paul Vincent. New York: Farrar, Straus and Giroux, 1994.

WRIGHT, R. H. The sense of smell. Boca Raton: CRC Press, 1982.

WNUK, Ewelina; MAJID, Asifa. Revisiting the limits of language: the odor lexicon of Maniq. Cognition, v. 131, i. 01, p. 125-138, April 2014. Disponível em: https://www.sciencedirect.com/science/article/pii/S0010027713002527. Acesso em: 02 maio 2019. 